\title{
PENGALAMAN DAN MAKNA KLIEN KETERGANTUNGAN NAPZA SAAT FASE AWAL KETERGANTUNGAN DI KABUPATEN SLEMAN
}

Rizqi Wahyu Hidayati ${ }^{1 *}$, Indah Winarni ${ }^{2}$, Septi Dewi Rachmawati ${ }^{3}$

\begin{abstract}
${ }^{* 1}$ Stikes Jenderal Achmad Yani Yogyakarta Jln. Ringroad Barat, Ambarketawang, Gamping, Sleman, D.I.Yogyakarta 55294, email ririzpl@gmail.com

${ }^{2,3}$ Staff Pengajar Magister Keperawatan Universitas Brawijaya Jln. Veteran, Ketawanggede, Lowokwaru, Kota Malang
\end{abstract}

\begin{abstract}
Background: Drug abuse has become a global problem, including in Indonesia, especially Yogyakarta. Yogyakarta is the province with the highest prevalence of drug abuse among students in Indonesia. Usage of drugs has a negative impact on health both physically and psychologically. However, based on preliminary studies, drug users continue to use the substance, althought they know its effect. The client experience of drug dependence when first trying the substance is interesting to look at.

Objective: The aim of this study was to explore the experiences of the pearticipant in their early stage of drug addiction in Sleman Regency.

Methods: The study method used qualitative with design of phenomenology intepretif, and use method of IPA as method of data analysis.

Results: Based on the results of the analysis of the phenomenology intepretif of the 9 participants obtained the theme of the results are as follows: Trying to be part of the world of drugs and drug self-control.

Conclusion: Someone uses drugs due to various things one of them improves self-existence. For future research is expected to take place at BNN or hospital to see a different experience.
\end{abstract}

Keywords: drug abuse, initial phase of drug abuse

\section{PENDAHULUAN}

Penyalahgunaan NAPZA telah menjadi masalah global, termasuk Indonesia. Kejadian ini dapat dilihat dari data pada tahun 2011 telah terdapat 2,23\% atau 4,2 juta orang dari total penduduk (berusia $10-59$ tahun). ${ }^{1}$ Di Yogyakarta merupakan propinsi dengan prevalensi tertinggi yang menyalahgunakan narkoba di kalangan pelajar dan mahasiswa di Indonesia, dengan angka 2,8 (untuk pemakai aktif) dan 6,6 (yang pernah pakai). ${ }^{2}$

Sedangkan di Kabupaten Sleman peningkatan pemakaian dan penyalahgunaan zat adiktif dikarenakan letak wilayah geografis yang strategis. Salah satu diantaranya yaitu sebagai jalur ekonomi utama di wilayah selatan Pulau Jawa. Selain itu Sleman juga sebagai pusat pendidikan. Hal ini ditunjukkan dengan jumlah universitas. Kabupaten ini memiliki 4 perguruan tinggi negeri dan 36 perguruan tinggi swasta. ${ }^{3} \mathrm{Hal}$ ini meningkatkan risiko terjadinya penyalahgunaan NAPZA. Selain itu peningkatan penggunaan NAPZA dikarenakan lingkungan pekerjaan, ketidakharmonisan keluarga, kelas sosial, ekonomi, kelompok sebaya, dan diri individu 
sendiri ${ }^{1}$. Sehingga penggunaan tersebut dapat memberikan dampak negatif bagi individu bahkan hingga kematian. ${ }^{4,5}$

Berdasarkan studi pendahuluan diketahui bahwa klien yang mengetahui jika itu adalah NAPZA, tetapi mereka tetap menggunakan zat tersebut. Hal ini merupakan pengalaman yang menarik untuk dilihat. Sehingga, penelitian ini bertujuan untuk melihat makna pengalaman dari klien yang mengalami ketergantungan NAPZA ketika fase awal ketergantungan zat.

\section{BAHAN DAN CARA PENELITIAN}

Metode yang digunakan dalam penelitian ini adalah studi kualitatif dengan design fenomenologi intepretatif. Studi fenomenologi bertujuan untuk melihat makna dari setiap pengalaman partisipan, berdasarkan peristiwa yang dilalui dan status partisipan. ${ }^{6}$ Sedangkan partisipan dalam penelitian ini terdiri dari 4 elemen yaitu actor, peristiwa, proses, dan setting. ${ }^{7}$ Di dalam penelitian ini actor yang digunakan adalah klien yang memiliki ketergantungan NAPZA. Pemilihan partisipan ini menggunakan porposive sampling dengan kriteria: tingkat ketergantungan tipe C, laki-laki, usia 20 - 40 tahun, lulusan SMA/ setara, dan klien adalah post discharge panti rehabilitasi minimal 6 bulan. Berdasarkan kriteria tersebut, maka di dalam penelitian ini terdapat 9 partisipan yang bersedia secara sukarela untuk menceritakan pengalamannya. Tehnik wawancara yang digunakan yaitu menggunakan semi terstruktur dan in depth interview. Kemudian peneliti melakukan analisis data dengan menggunakan Intepretative Phenomenological Analysis (IPA). Kemudian keabsahan data menggunakan Lincold and Guba. Selain itu peneliti telah melakukan uji etik di Universitas Brawijaya dan telah dinyatakan layak etik.

\section{HASIL DAN PEMBAHASAN}

Penelitian ini menghasilkan sepuluh tema berdasarkan analisis menggunakan IPA yaitu Reading and Re-reading (membaca berulang-ulang), InitiaL noting (memberikan penjelasan pada kata-kata yang unik serta menggarisbawahi teks-teks yang dianggap penting), mengembangkan kemunculan tema (membuat mapping hasil temuan), mencari hubungan antar tema-tema yang muncul, mengulang proses pada partisipan $2-9$ seperti yang telah dilakukan, mencari polapola yang muncul antar kasus, dan terakhir membuat metafora tema. ${ }^{6,8}$ Tema yang dihasilkan tersebut adalah Mencoba menjadi bagian dari dunia NAPZA dan NAPZA menguasai diri. Penjelasan mengenai tematema yang dihasilkan yaitu:

Tema 1: Mencoba menjadi bagian dari dunia $N A P Z A$

Pemahaman makna tema satu, mencoba menjadi bagian dari dunia NAPZA secara harfiah adalah tindakan yang bertujuan untuk 
mengetahui tentang lingkungan atau lapangan kehidupan berhubungan dengan NAPZA. Tema ini terbangun dari 2 sub tema dan 2 sub-sub tema.

Sub tema pertama yaitu memenuhi hasrat ingin tahu dengan mencoba NAPZA. Hal ini diartikan sebagai memuaskan keingintahuan yang kuat dengan mencoba NAPZA tersebut.

"Ya Narkoba, saya sudah paham Mbak. Tapi ya rasanya pingin tahu, pingin merasakan jadi ya nggak apa-apa. Dulu saya juga nggak tahu kalau bakal pingin terus kayak gini. Saya pahamnya ya itu barang cuma ngefek di badan. Kalau badan rusak ya dibenerin kan ada dokter..." (P.1)

“... Trus tak ambil, trus saya Tanya-tanya sendiri "ini tuh obat apa?". Kok penasaran, pingin ngrasain... Nggak tahu waktu itu, ya cuma karena penasaran itu. Obat gimana, pingin tahu rasanya. Trus lama kelamaan kok nyandu... Belum tahu sama sekali. J adi ya murni coba-coba" (P.2)

Penggalan pernyataan partisipan tersebut dapat diartikan sebagai seseorang memiliki dorongan yang kuat untuk mengetahui lebih banyak tentang narkoba dengan cara menggunakannya. Bahkan, ada partisipan yang tidak mengetahui sama sekali tentang NAPZA sehingga memicu keingintahuan mereka. Rasa ingin tahu tersebut menimbulkan keinginan kuat untuk mencoba zat tersebut.

Sub tema kedua yaitu mengidentifikasi diri dengan teman sebaya di lingkungan sosial. Hal ini diartikan sebagai upaya seseorang untuk menentukan identitasnya di dalam lingkungan kelompok pertemanan. Pernyataan ini dapat dilihat dari penggalan pernyataan partisipan yaitu

"Jadi lingkunganku udah beda. Kumpulnya sama orang-orang yang lebih tua dan mungkin bisa dikatakan yaa... lebih dewasa... bisa dikatakan juga mereka liar apa ya... karena lebih mengenal semua itu... Pemahaman pertamaku ya.... Udah tahu sih kalau itu obat orang gila gitu, dan kalau termasuk narkoba. Tapi... aku pingin gaul e... aku pingin kaya mereka, aku pingin ikut komunitas" (P.3)

"Yo... tahu kalau itu narkoba, tapi dengan mencoba, jadi tahu yang sebenernya efeknya apa. Sebelumnya kan hanya diberitahu temen... Efeknya ya nggak bisa tidur, nggak mau makan berat, paling minum. Dan yang tak rasakan ya bener seperti yang dibilang, ditambah tambah pinter..." (P.4)

Berdasarkan penggalan tersebut dapat dilihat bahwa teman sebaya dan kelompok memiliki peran penting dalam proses seseorang menjadi penyalahguna zat. Selain 
itu, seseorang ingin masuk ke dalam komunitas pergaulan dengan mengikuti kegiatan yang ada di komunitas tersebut

\section{Tema 2: NAPZA menguasai diri}

Makna tema tersebut bahwa NAPZA mampu mengendalikan individu. Sedangkan secara kontekstual dapat terlihat melalui pernyataan partisipan. Tema ini terdiri dari 2 sub tema. Sub tema pertama adalah merasakan kehilangan daya hidup. Hal ini dikarenakan partisipan akan merasakan efek zat adiktif jika tidak menggunakan. Pernyataan ini terlihat dari:

"Udah pakek, itu kan zat adiktif ya, nyandu. Itu kalau makek, hari ini makek obat-obatan atau apa lah, trus selang 1, 2, 3 hari nggak makek itu badan sakit. Kita pasti meriang. ... kalau tidak dimasukkan zat itu badan rasanya lemes, tapi kalau udah pakek ya sudah sehat." (P.2)

Hal ini diartikan sebagai partisipan merasa dalam kondisi sakit yang dirasakan oleh badan dan jiwa jika tidak menggunakan zat adiktif tersebut. Sehingga pemakaian zat adiktif dilakukan secara reguler. Sub tema dua yaitu merasa ketergantungan dari diri kita sendiri. Ini diartikan bahwa seseorang tersebut memahami bahwa NAPZA dan dia memiliki hubungan yang erat, tetapi yang mampu mengontrol penggunaan ya individu tersebut. Pernyataan ini sesuai dengan petikan wawancara yaitu:

“... Kalau misalkan bisa mengontrol ego kita, ya tidak ketergantungan." (P.4)

Sub tema terakhir yaitu selalu merasakan haus akan zat adiksinya. Sub tema ini diartikan yaitu individu tersebut terlalu menginginkan zat adiksinya tersebut. Partisipan merasa tidak puas dan selalu memiliki keinginan untuk menggunakan serta mencari zat secara berkelanjutan. Hal ini sesuai dengan pernyataan partisipan yaitu:

"Dulu itu dosisnya... 3 kali isap biasanya ngrasa enak. Tapi 5 isep gitu, kaya... Dosisnya tambah tinggi nambah tinggi gitu, malah nggak bisa ngrasain. Kan udah biasa-biasa." (P.8)

“... Udah nggak gagas, nggak peduli. Namanya udah kecanduan. Saya dulu juga pernah kehabisan barangnya sekali atau dua kali itu. Trus ya saya cari gimana carane dapat barang itu." (P.1)

Berdasarkan paparan pada ketiga sub tema dan sub-sub tema tersebut dan pernyataan partisipan, maka dapat disimpulkan bahwa zat adiktif tersebut telah mempengaruhi baik secara fisik dan psikologis dari pengguna. 
Penyalahguna NAPZA pada awalnya memiliki pemahaman yang beragam mengenai NAPZA. Sehingga pengalaman saat menggunakan pertama kali menarik untuk diulas. Ketidakpahaman tentang NAPZA memicu rasa ingin tahu individu tersebut untuk mencoba. Beberapa pengguna awal merasa sudah tahu bahwa zat tersebut adalah NAPZA, tetapi tidak memahami dampak atau efek dari penggunaan zat adiktif tersebut. Hal ini sesuai dengan pernyataan Purba, Wahyu, Nasution, \& Daulay bahwa rasa ingin tahu dan dorongan kenikmatan mampu mendorong seseorang untuk menyalahgunakan NAPZA. ${ }^{9}$ Selain itu Purba et al. juga menyebutkan bahwa eksistensi diri dinilai mampu menjadi pemicu seseorang untuk mencoba NAPZA. ${ }^{10} \mathrm{Hal}$ ini dikarenakan teman sebaya memberikan pengaruh besar terhadap perilaku penggunaan narkoba. Penyebabnya yaitu karena individu tersebut merupakan bagian dari kelompok, sehingga ia juga ingin melakukan hal-hal yang dilakukan oleh anggota kelompok lain. Pernyataan ini disetujui oleh Fisher, Manoogian, \& Hoover dan Janssen, Mathijssen, Van Bon-Martens, Van Oers, \& Garretsen bahwa kelompok sebaya meningkatkan keinginan untuk menggunakan NAPZA karena mereka cenderung tidak dapat menolak ajakan anggota kelompok lain. Penyalahguna juga menganggap bahwa mereka merasa lebih bahagia dengan komunitas yang menggunakan NAPZA. ${ }^{11,12}$ Kondisi ini sesuai dengan kondisi partisipan bahwa kelompok memiliki peran penting untuk memotivasinya menggunakan zat adiktif tersebut. Sartre mengungkapkan bahwa bad faith adalah elemen dan faktor yang dapat mempengaruhi identitas diri di luar individu tersebut. Berdasarkan teori tersebut maka seseorang memiliki bad faith apabila ia terpengaruh lingkungan dalam menemukan identitas diri. ${ }^{13}$

Setelah tahap mencoba, individu tersebut akan memasuki tahap penyalahguna. Tahapan ini, partisipan merasa zat adiktif tersebut mempengaruhi secara fisik dan psikisnya. Berbagai masalah timbul jika mengurangi dosis atau memutus penggunaan, salah satunya yaitu gangguan putus zat. ${ }^{14,15}$ Selain fisik, psikis dirasakan seperti mudah marah, tidak ada semangat hidup, waham ${ }^{16}$, dan gangguan pada hubungan sosial ${ }^{10}$. Sehingga, partisipan tersebut akan mengalami toleransi zat, ditandai dengan penambahan dosis ${ }^{14}$. Jika tidak dikendalikan maka ia akan menambah dosis secara berkelanjutan. Dengan demikian ketika penyalahguna menghentikan pemakaian maka ia akan mengalami craving dan terjadi relaps di kemudian hari ${ }^{18}$. Hal ini dikarenakan penyalahgunaan NAPZA merupakan penyakit yang tidak dapat disembuhkan ${ }^{17}$. 


\section{KESIMPULAN}

Penyalahgunaan zat merupakan penyakit kronis yang tidak dapat disembuhkan. Pada awal pemakaian klien memiliki berbagai motivasi untuk tetap menggunakan NAPZA. Namun, mereka kurang memahami efek dari penyalahgunaan adalah ketergantungan. Keterbatasan penelitian ini yaitu penelitian hanya mencakup klien yang sudah mendapatkan perawatan di panti rehabilitasi saja. Sehingga, Peneliti menyarankan penelitian selanjutnya mengambil setting penelitian di rumah sakit atau BNN yang memiliki latar belakang klien yang berbeda dan metode pemulihan yang berbeda juga.

\section{KEPUSTAKAAN}

1. United Nation On Drug and Crime (UNODC). World Drug Report 2013. Bangkok, Thailand

2. BNN \& Pusat Penelitian Kesehatan Universitas Indonesia. Hasil Survei Penyalahgunaan dan Peredaran Gelap Narkoba Pada Kelompok Pelajar dan Mahasiswa di 18 Provinsi Tahun 2016. Jakarta

3. Sleman. Prasarana dan Sarana. Diunduh di

https://www.slemankab.go.id/210/prasara na-dan-sarana.slm. Pada Pada 17 Juni 2017

4. National Institute on Drug Abuse. Physical and Psychological Effects of Substance Use. U.S Department Of Health And Human Services. Maryland. 2004
5. UNODC ${ }^{b}$. World Drugs Report 2016 Executive Summary. UNODC Research. 2016

6. Hajaroh, M. Paradigma, Pendekatan dan Metode Penelitian Fenomenologi. Jurnal IImiah FIP Universitas Neberi Yogyakarta, 1-21. 2009

7. Creswell, J. W. Research Design: Pendekatan Kualitatif, Kuantitatif, dan Mixed. (3rd ed.). Pustaka Pelajar. 2010

8. Finley, Linda. Phenomenology for Therapist: Researching The Lived World. First Ed. John Wiley \& Sons, Ltd. 2011

9. Purba, Wahyuni, Nasution, \& Daulay. Asuhan Keperawatan Pada Klien Dengan Masalah Psikososial dan Gangguan Jiwa. Medan: USU Press. 2008

10. Saleh, H. D., Rokhmah, D., \& Nafikadini, I. Fenomena Penyalahgunaan NAPZA Di Kalangan Remaja Ditinjau Dari Teori Interaksionisme Simbolik Di Kabupaten Jember (The Phenomenon of Substance Abuse among Adolescents Based on Symbolic Interactionism Theory in Jember Regency), 2(3), 468-475. 2014

11. Fisher, K., Manoogian, M. M., \& Hoover, S. " Drugs was My Solution -- My Problem was Life ": Heroin Addiction and the Life Course Perspective "Drugs was My Solution -- My Problem was Life ": Heroin Addiction and, 5. 2016

12. Janssen, M. M., Mathijssen, J. J. P., van Bon-Martens, M. J. H., van Oers, H. A. M., \& Garretsen, H. F. L. A qualitative exploration of attitudes towards alcohol, and the role of parents and peers of two alcohol-attitude-based segments of the adolescent population. Substance Abuse Treatment, Prevention, and Policy, 9, 20. 2014 https://doi.org/10.1186/1747-597X9-20

13. Mozaffaripour \& Hamrah. The concept of authenticity in philosophy of Sartre and implications for using internet as 
educational technology. Int. J. Advanced Networking and Applications. Volume 07. Issue 02. Pages 2658 - 2665. 2015 ISSN: 0975-0290

14. Maslim. Diagnosis Gangguan Jiwa, Rujukan Ringkas PPDGJ-III dan DSM-V. Bagian IImu Kedokteran Jiwa FK Unika Atma Jaya. Jakarta. 2013

15. Sulistami, Yulia, \& Tegawati. Bahaya NAPZA. Jakarta: PT. Mustika Cendekia Negeri. 2013

16. Nurjanisah, Tahlil, \& Hasballah. Analisis Penyalahgunaan NAPZA dengan Pendekatan Health Belief Model. Jurnal IImu Keperawatan. Vol 5, No. 1, 2017 ISSN: 2338-6371

17. Saltz, Larson, LaBelle, Richards, \& Samet. The case for chronic management for addiction. National Institute of Health. $J$ Addict Med. June 1; 2 (2). 2008

18. Fredericks, J., \& Samuel, E. (2014). Drugs and Recovery: A Qualitative Study in Atlantic Canada. Aijssnet.Com, 3(2), 28-34. Retrieved from http://www.aijssnet.com/journals/Vol_3_N o_2_March_2014/4.pdf 